\title{
Research on Precise Funding for the Education of Poor Students of Ethnic Minorities
}

\author{
Mi Wei \\ School of Nursing \\ Xi'an Medical University \\ Xi'an, China 710021
}

\begin{abstract}
Superficially, the financial aid work for the poor students is to solve the economic problems of the students. The significance of ideological and political education is to solve the deeper ideological and cognitive problems, so as to promote the transformation of the financial aid work to "supporting the will" and "supporting the intelligence", and help the poor students to establish the will and character of selfimprovement, self-esteem and self-confidence. The financial aid for the poor students of ethnic minorities faces some challenges, such as inaccurate affirmation of the poverty of ethnic students, insufficient attention to the employment guidance of ethnic students, lack of psychological guidance for ethnic students in the process of subsidizing the students, and lack of systematic education in coordination with the work of subsidizing education of ethnic students. Therefore, it is necessary to pay attention to grasp the foundation of education in the financial aid, realize the financial funding for the education of ethnic minority, and help the students who have financial difficulties grow up and complete their studies.
\end{abstract}

Keywords - colleges and universities; ethnic minorities; college students; precise funding

\section{INTRODUCTION}

The minority college students, especially the minority college students in the western region, mostly come from the underdeveloped areas, and their family is generally not very good in the economics. How to help the ethnic minority students with financial difficulties to complete their studies smoothly, especially how to consider and solve the special difficulties of ethnic minority college students under the overall design of the national award and assistance system, and how to better realize the funding and education are the important issues faced by colleges and universities at present

\section{The Challenges of the Financial Aid For PoOR MinORITY STUDENTS FACED BY COLLEGES AND} UNIVERSITIES

\section{A. The Poverty Affirmation of Ethnic Minority Students is Not Accurate Enough}

At present, China has invested a lot of energy in the financial aid for the ethnic minority, but it is still not accurate in the affirmation work. In different minority areas, the level of economic development is very different. The definition of poverty level should be different. Comparing the poverty level of each region horizontally, it is not difficult to find the difference among the financial difficulty levels. Each school has its own criteria for determining the poverty level, and there are different methods for affirming the poverty level. In this way, students of the same financial difficulty level will enjoy different treatment in different schools.

The degree of family difficulty is not unchangeable. After the affirmation of poverty level, some students' families may suffer from sudden changes and will be poor due to illness. If it is not affirmed again in the later stage, it can't meet the student's funding needs. Among them, there are also some students with strong self-esteem, or they have low self-esteem due to the economic difficulties of their families. And they do not want their difficulties to be known by others. This self-esteem and self-abasement affect their acceptance of financial aid, and they can't reduce the burden of their families.

\section{B. Insufficient Attention to Employment Guidance for Ethnic Minority Students}

There are some problems in the employment guidance team of minority universities, such as the insufficient employment professional guidance staff and the weak professional staff. The specific performance is as follows: first, due to the expansion of universities and colleges, the number of students has increased massively. Therefore, although more than half of minority universities have set up special institutions and equipped with full-time personnel to take charge of the work of career guidance, there is still an obvious imbalance between the number of career guidance staff and students. Moreover, the staff lacks the energy of employment guidance and can't provide high-quality services due to the busy daily affairs. The professional quality of the employment guidance personnel is not strong and they don't have excellent professional level. In the daily guidance, the staff did not start from the immediate interests of students, and the awareness of serving students was relatively weak, and there were work attitude problems.

At present, the work of employment guidance for ethnic minorities is mainly to collect and release employment information and analyze the employment situation, while the focus on the employment mentality of students and the content of the employment outlook and entrepreneurship 
outlook is relatively lacking. On the other hand, the course content selected by the employment guidance is utilitarian, and only focuses on the teaching of students' job-hunting skills, interpersonal relationship processing, interview skills and other aspects. Although these are indispensable contents of the guidance, only one-sided and single guidance is not conducive to the long-term development of students' work, but also leads to the lack of hard-working dedication and entrepreneurship of students. Students are short-sighted and only pay attention to the immediate interests of work, which is not conducive to students' career planning.

\section{Lack of Psychological Guidance for Ethnic Minority Students in the Process of Financial Aid}

For students with financial difficulties, colleges and universities will actively carry out financial assistance so that students can successfully complete their studies without being deprived of education because of family financial difficulties. How much attention should be paid to the psychological problems of the assisted students? The original family has a very big impact on a person, and this impact may be a lifetime impact. Compared with the two students with good family economic conditions and poor family economic conditions, their psychological states are often different. Students with good family economic conditions will show a state of self-confidence and a positive attitude towards the whole society. Comparatively speaking, the students with poor family economic conditions will feel inferior in heart. They are unwilling to let others know their family situation and have a relatively negative attitude towards their life.

Poor students are more likely to have psychological problems than other students, which seriously affects their study and life. They often have such psychological states as inferiority, pessimism and anxiety, sensitivity and extreme psychology, and a small number of poor students with weak will show the psychology of dependence and laziness, even individual has extreme hatred and revenge mentality. The school's psychological guidance for such students is urgently needed. Without a healthy psychology, students' study and employment will be potentially affected.

\section{Lack of Systematic Education in Coordination with the Work of Financial Aid for Ethnic Minority Students}

Colleges and universities attach great importance to financial aid to students with financial difficulties. However, it lacks systematic education matching with the financial aid for poor students of ethnic minorities. This problem is mainly reflected in two aspects: first, the financial aid for the poor minority students is paid less attention, and the management system is relatively backward. The financial aid for education is an important ideological and political education, which has an important impact on the ideological and moral character of college students. However, through the investigation and research, it can find that the number of full-time teachers in financial aid work is insufficient, which can't meet the needs of financial aid work. There are only 2-3 teachers in charge of financial aid in a university. As a result, they are only tired of dealing with daily work, and have no energy to do education work.

\section{The PRACTICE PATH OF PRECISE FinANCIAL AID FOR POOR MINORITY STUDENTS IN COLLEGES AND UNIVERSITIES}

The work of university financial aid is closely related to the ideological and political education of college students. It should not pursue short-term interests in a single or onesided way and ignore the integrity and systematization of ideological and political education. Otherwise, it will not be able to realize the original intention of financial aid for education, and even affect the overall effect of financial aid for poor students. As for the financial aid for ethnic minority college students with family economic difficulties, colleges and universities should make comprehensive thinking, indepth analysis, and focus on research and judgment, so as to better guarantee the overall development and growth of poor students.

\section{A. Accurate Affirmation is the Premise of Precise Financial Aid}

It is necessary to firmly grasp the precise requirements, strengthen the link control, strengthen the management, pay attention to the classified implementation of policies, improve the accuracy of financial aid, and ensure the implementation of funding policies.

First, colleges and universities can take the way of organizing teachers' investigation, on-the-spot visit and students' democratic evaluation, so as to accurately affirm the students who need to be funded. Then, the efficiency of university funding can be greatly improved and the education equity will be promoted. Second, it is possible to establish an accurate affirmation system for students with financial difficulties in colleges and universities. And it can accurately affirm the objects and levels of financial assistance through the four key points from enrollment to graduation. Colleges and universities will strictly enforce the registration of new students and establish a green channel to ensure that students do not drop out of school due to family difficulties. Also, colleges and universities should strictly control the overall screening, carry out family economic investigation for the students of the whole school, and establish the growth archive of students with family economic difficulties. At the same time, it is necessary to establish a declaration mechanism for the major difficulties of poor students. In case of major diseases of students, colleges and universities can start the medical insurance for serious diseases and financial aid for temporary difficulties to alleviate the financial difficulties of students. Third, colleges and universities can hold symposiums with students of ethnic minorities from time to time. Through the discussion and exchange with students, the colleges can directly grasp the economic situation of students' families, and make clear about the situation of the family. For students with financial difficulties, the colleges should have a clear plan to help them with precise financial aid. Through these systems, it can ensure the continuous standardization of the financial aid and the accuracy of the affirmation of the funding for poor students. 
universities should make full use of the role of party members, cadres, counselors and head teachers. By talking with poor students in time, the colleges can timely understand the life of poor students, their ideological changes and psychological fluctuations. Once the colleges find out the difference, the colleges and universities should timely conduct necessary and effective psychological counseling to the students who have unhealthy tendency or whose psychology is on the edge of danger, track their psychological situation to a certain extent, and record their situation in the psychological consulting room for a registration.

Third, the colleges and universities can strengthen the "psychological resilience" of poor students through mental health education. When an individual is faced with some stress events, the ability of psychological mechanism to recover and maintain adaptability is called psychological resilience. It is a dynamic and positive psychological process, and it is an individual's adaptability in the face of major life adversity. In view of this situation, the guidance staff should encourage the poor students to strengthen communication with others and exchange advantages, consciously cultivate and improve their psychological resilience level; encourage students to participate in various extracurricular practice activities, and exercise their ability to get along with others and social adaptability.

\section{Establishing and Improving the Management Mode Suitable for the Financial Aid}

A professional team should be set up to carry out dynamic management and continuous supervision on the poor students of ethnic minorities, so as to promote the sustainable development of funding for education.

First, colleges and universities should cultivate a professional backbone team to provide financial aid for poor students of ethnic minority. The funding work for the education is mainly the interactive communication process between the staff and the poor students. Therefore, the professionalization of this team is very important, which is the premise and foundation of providing the financial aid for students. The colleges and universities can't put the responsibility of educating people on the counselors. It is necessary to set up a clear team and a clear system, so as to make the responsibility clear. It also should make strict requirements for the key team members and assess their basic professional quality. Colleges and universities should guarantee the funds and material support for the activities of the teams of providing financial aid, and make their work smoothly.

Second, colleges and universities should build a platform for providing financial aid for the education. Colleges and universities can set up a special app for providing financial aid for students. The counselors and professional staff can download and use it. Through mobile phones, students can receive direct education. Also, this app builds a bridge for communication between teachers and students. Students can ask questions on the app if they have any doubts. Teachers can answer questions online after receiving the questions and
Second, it is convenient to make a regular interview system for poor students. At this time, the colleges and 
provide some online services. It can also be carried out through the WeChat Official Accounts. At present, every university has a WeChat Official Account with exclusive funding, but its functions are few and its usage is not frequent. More functions should be developed to facilitate teachers and students to discuss some problems in WeChat Official Accounts.

Third, it can give more play to the strength of student cadres. In particular, colleges and universities should give full play to the value of the cadres of ethnic minority students. It is more convenient for them to communicate with the poor ethnic minority students, and it is easy for them to be convinced. The student cadres and the poor students can form a assist group. With the "one-to-one" or "one-tomany" method, the student cadres can understand the needs and status of the poor students, so as to improve the pertinence and quality of financial aid. Student party members are a strong team, and they are also useful supplement and reserve force to support the team of providing financial aid.

\section{CONCLUSION}

Colleges and universities are the main body that provides financial aid. It is necessary to set up the principle of serving students. Colleges and universities should not only help students economically, but also should attach importance to the growth and development of students. The purpose of helping the students is to achieve the goal of strengthening moral education and cultivating people, to liberate the students from the shackles of economy and environment, and to realize its all-round development. However, the real realization of financial aid requires efforts from all aspects, all staff and the whole process to prevent the alienation of people and the distortion of students' values, so that they can get rid of the vulgar concept of money and see the truth, goodness and beauty of human nature.

\section{REFERENCES}

[1] Shen Hong. The theory and practice of college student financial aid in China [M]. Beijing: China Social Science Press, 2016. (in Chinese)

[2] Liang Guoping. Exploration and Practice of Aid Education of Universities and Colleges [M]. Sichuan: Southwest Jiaotong University Press, 2015. (in Chinese)

[3] Tang Yuqin. A multi-dimensional perspective of college students with financial difficulties [M]. Beijing: China Book Publishing House, 2015. (in Chinese) 